\title{
Література:
}

1. Тесленко І.О. Шляхи вдосконалення робочих органів універсальних землерийних машин // Науково-технічний збірник «Вісник Національного транспортного університету» Київ 2016. Випуск 2 (35). C. 211-218.

2. Аулін В.В., Тихий А.А., Карпушин С.О., Деревянко Д.А. Підвищення енергоефективності обробітку грунту зменшенням процесів його налипання на поверхні робочих органів. Центральноукраїнський науковий вісник. Технічні науки. Кропивницький 2019. Випуск 2 (33). C. 3-16. DOI: https://doi.org/10.32515/2664-262X.2019.2(33).3-16

3. Голубченко O.I., Хожило М.Е., Огляд та пропозиції конструкцій активного робочого обладнання землерийно-транспортних машин безперервної дії // Вісник Придніпровської державної академії будівництва та архітектури. Дніпро 2011. Випуск 6-7. С. 48-55.

4. Пат. 4920 Україна, Ківш скрепера МПК Е02F 3/64. Заявл. 24.05.2004; Опубл. 15.02.2005. бюл. №2 Авт. Хмара Л.А., Карпушин С.О., Старунський С.В.

5. Пат. 35362 Україна, Робоче обладнання одноківшового екскаватора МПК Е02F 3/28. Заявл. 29.04.2008; Опубл. 10.09.2008. бюл. № 7 Авт. Карпушин С.О.

DOI https://doi.org/10.30525/978-9934-26-046-9-24

\section{REGULAR THERMAL REGIME OF A SYSTEM OF BODIES}

\author{
Peretiaka N. O. \\ Ph. D. of Engineering Sciences, Associate Professor \\ Odesa State University of Intelligent Technologies and Communications \\ Odesa, Ukraine
}

Rolling bearings are widely used in machines. Good bearing performance depends on the correct calculation of the maximum load. There is a lot of research in the field of vibration and acoustic diagnostics. But the thermal control method remains very effective in detecting faults [1].

Works $[2,3,4]$ are devoted to the study of heat transfer in rolling bearings. However, studies on the regular thermal conditions of rolling bearings are not enough.

Consider a rolling bearing as a composite body, consisting of several parts, the materials of which differ significantly in thermal properties. For 100 
brevity, such a composite body will be called a system. Let the heat exchange on the outer side S of the system obey Newton's law:

$$
\lambda_{i}=\left.\left(\frac{\partial\left(t_{i}-t_{o}\right)}{\partial n_{i}}\right)\right|_{s}+\left.\alpha_{i}\left(t_{i}-t_{o}\right)\right|_{s}=0,
$$

where $i-$ is the number of the part of the system that is in contact with the external environment.

We will assume that the $\lambda_{i}, \alpha_{i}$ parameters do not depend on temperature. This will make it possible to apply the first theorem of Kondrat'ev [5] to this system and assume that the temperature field is regularized in the system.

In a system of bodies that is cooled or heated in a thermostated convective medium, as in a homogeneous body, over time, the temperature field inevitably occurs. This means that the rate of change of the logarithm of the excess temperature $\partial\left(\ln \vartheta_{\text {reg }}\right)$ from time to time remains the same for all points of the system.

Graphically, the temperature field of the system $\vartheta=f(\tau)$ is depicted in semilogarithmic coordinates by a family of parallel straight lines (Fig. 1), that is, it remains similar to itself, as in the case of a simple body.

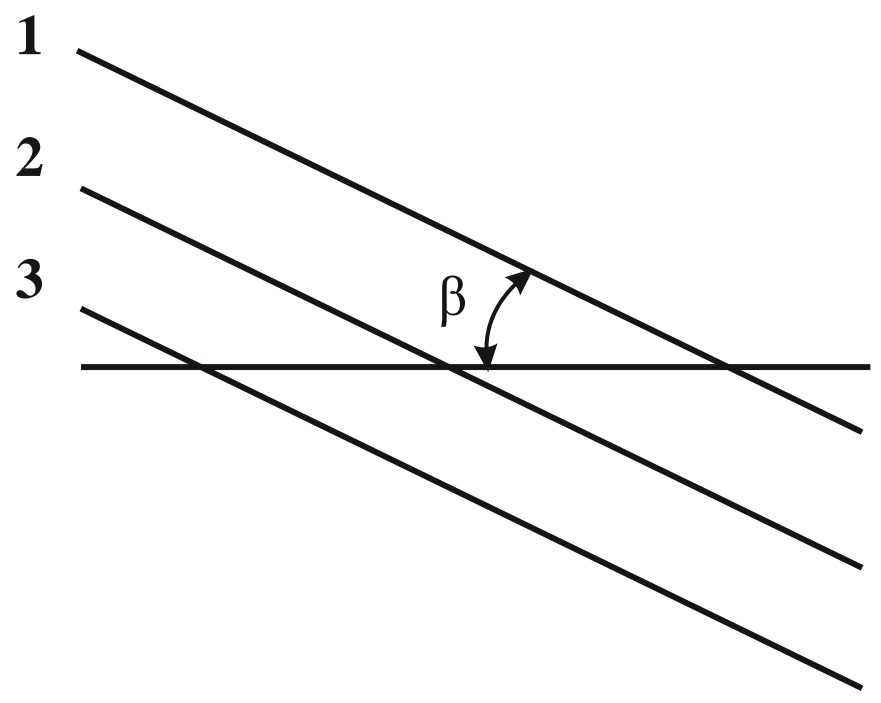

Fig. 1. System temperature field 
Regular heating mode characterizes the heating rate [6]:

$$
m=\frac{\ln \vartheta-\ln \vartheta_{e}}{\Delta \tau}=\text { const }
$$

where $\vartheta$ - object temperature, ${ }^{\circ} \mathrm{C} ; \ln \vartheta_{e}-$ ambient temperature, ${ }^{\circ} \mathrm{C} ; \Delta \tau$ - time, minutes.

For the system, the heating rate $m$ depends on a large number of parameters:

- on the shape and size of the system and the relative position of its parts;

- on the thermophysical properties of the materials that make up the system;

- on the conditions of heat transfer on the outer surfaces of the system; system.

- on the conditions at the interfaces between adjacent parts of the

For the system, as well as for a simple body, the law of asymptotic increase of $m$ with increasing $\alpha$ is fulfilled, and the $\operatorname{limit}_{\alpha \rightarrow \infty} m=m_{\infty}$ a finite quantity.

Thus, in a rolling bearing, a regularization of the temperature field inevitably occurs over time. The heating rate of the rolling bearing is not constant and depends on the shape, size, material properties of the elements, heat transfer conditions and the conditions of the element boundaries.

\section{References:}

1. D. Belmiloud, M. Lachi, H. Pron, F. Bolaers, J.-P. Dron, X. Chiementin, A. Laggoun, Thermo-dynamical modelisation of the degradation of a ball bearing in variables use conditions, Mechanics \& Industry. №21(608). 2020. 14 p. DOI: https://doi.org/10.1051/meca/2020083

2. Y. Muzychka, M. Yovanovitch, Thermal resistance models for non circular moving heat sources on a half space, Transaction of the ASME, Journal of Heat Transfer. №3. 2001. P. 624-632.

3. A. Baïri, N. Alilat, J.G. Bauzin, N. Laraqui, Three dimensional stationary thermal behavior of a bearing ball, International Journal of Thermal Sciences. №6. 2004. P. 561-568. https://doi.org/10.1016/ j.ijthermalsci.2003.10.008

4. K. Yan, Y.T. Wang, Y.S. Zhu, Investigation on heat dissipation characteristic of ball bearing cage and inside cavity at ultra-high rotation speed, Trib. Int. №93, 2016. P. 470-481. https://doi.org/10.1016/ j.triboint.2015.09.030 
5. Кондратьев Г.М., Дульнев Г.Н., Платунов Е.С., Ярышев Н.А. Прикладная физика: Теплообмен в приборостроении. СПб.: СПбГУ ИТМО, 2003. $560 \mathrm{c}$.

6. Peretiaka N., Boriak K., Vatrenko O. Improving the thermal method for assessing the technical condition of rolling bearings based on the heating rate criterion. Eastern-European Journal of Enterprise Technologies. № 5/1 (107). 2020. P. 118-126. DOI: https://doi.org/10.15587/17294061.2020.212540

DOI https://doi.org/10.30525/978-9934-26-046-9-25

\title{
SIMULATION OF PROCESSING WITH ABRASIVE SUBSTANCE OF ANGULAR RECTANGULAR WAVEGUIDE CHANNEL
}

\author{
Tryshyn P. R. \\ Postgraduate Student at the Department of Technologies \\ of Mechanical Engineering \\ National University «Zaporizhzhia Polytechnic» \\ Honchar N. V. \\ Ph.D., \\ Associate Professor at the Department of Technologies \\ of Mechanical Engineering \\ National University «Zaporizhzhia Polytechnic»

\section{Lahovskyi O. V.} \\ Student at the Department of Technologies of Mechanical Engineering \\ National University «Zaporizhzhia Polytechnic» \\ Zaporizhzhia, Ukraine
}

Rectangular waveguides with numerous bends and twists are applied in the S-range radars. There are two types of waveguide bends: smooth curves, which are made by bending the waveguide tube, and angular bends, which are made by welding or brazing sections of the waveguide tube. Angular ones are used more often, as they are more compact (Fig. 1). Waveguides are made from a thin-walled $(2.5 \mathrm{~mm})$ rectangular pipe, the material is aluminum or brass. 